Reprinted with permission from: Weed Technology. 1990. 4:635-641.

Published and copyrighted by: Weed Science Society of America. http://www.wssa.net

\title{
Cost-effective long-term leafy spurge (Euphorbia esula) control with herbicides ${ }^{1}$
}

\author{
RODNEY G. LYM and CALVIN G. MESSERSMITH \\ Lym and Messersmith are Assoc. Prof. and Prof., Crop and Weed Science Dep., N. D. State Univ., Fargo, ND 58105, \\ respectively.
}

\begin{abstract}
:
Four herbicide treatments applied in the spring or fall were evaluated for leafy spurge control and forage production in eastern and western North Dakota during a 5-year experiment. All treatments gradually reduced the leafy spurge infestation at both locations except 2,4-D at $2.2 \mathrm{~kg}$ ae/ha applied annually in the spring or fall and picloram plus 2,4-D at 0.28 plus 1.1 $\mathrm{kg}$ ae/ha applied annually in the fall. The most cost effective treatment was picloram plus 2,4-D applied annually in the spring which provided a net return of $\$ 284$ and $\$ 108 /$ ha in eastern and western North Dakota, respectively, and averaged $80 \%$ leafy spurge control. Picloram at $2.2 \mathrm{~kg} / \mathrm{ha}$ was reapplied only when leafy spurge control declined to less than $70 \%$ and provided a net return of $\$ 96 /$ ha in eastern North Dakota, but a net loss of $\$ 235 /$ ha in western North Dakota. Dicamba at $9 \mathrm{~kg}$ ae/ha was applied up to four times to maintain $70 \%$ control with an average net loss of $\$ 458$ / ha. Total potential production and value of forage will determine if a specific treatment is cost effective in any one location.
\end{abstract}

\section{Nomenclature:}

Dicamba, 3,6-dichloro-2-methoxybenzoic acid; picloram, 4-amino-3,5,6trichloro-2-pyridinecarboxylic acid; 2,4-D, (2,4-dichlorophenoxy)acetic acid; leafy spurge, Euphorbia esula L. \#² EPHES.

\section{Additional index words:}

Forage production, dicamba, picloram, 2,4-D.

\footnotetext{
${ }^{1}$ Published with approval of the Director, Agric. Exp. Station., N. D. State Univ. as J. Art No. 1825.

${ }^{2}$ Letters following this symbol are a WSSA-approved computer code from Composite List of Weeds, Revised 1989.

Available from WSSA, 309 W. Clark St., Champaign, IL 61820.
} 


\section{Introduction}

The influence of leafy spurge control on long-term land value is difficult to assess (9). However, short-term returns can be estimated by measuring changes in forage production and use by livestock following leafy spurge control $(3,4)$. Picloram at $2.2 \mathrm{~kg} / \mathrm{ha}$ will provide $>90 \%$ leafy spurge control for at least two growing seasons but costs about $\$ 200 /$ ha which is too expensive for use on large infestations $(5,7)$. Picloram applied with a roller applicator will give 80 to $90 \%$ leafy spurge control but costs over $\$ 80 /$ ha, requires retreatment after 2 years, and is practical only in areas of even terrain $(4,10)$. If leafy spurge is in an area that can be treated annually, then picloram plus $2,4-\mathrm{D}$ at 0.28 plus 1.1 $\mathrm{kg} / \mathrm{ha}$ may be the most cost-effective treatment $(6,8)$. Dicamba at $9 \mathrm{~kg} / \mathrm{ha}$ satisfactorily controls leafy spurge for only 1 year (6) but may be useful in areas where picloram cannot be used.

Leafy spurge reduces the livestock carrying capacity of pasture and rangeland 50 to $75 \%(1,13)$. In North Dakota, cattle used 20 and $2 \%$ of the forage available in zero- and low- $(<20 \%$ cover) density leafy spurge infestations by mid-season (3). Moderate- and high-density infestations were avoided until early fall when the milky latex in leafy spurge disappeared. Leafy spurge canopy cover of $10 \%$ or less and shoot control of $90 \%$ or more were necessary to achieve $50 \%$ forage use by cattle in Montana (2).

The purpose of this experiment was to evaluate leafy spurge control, forage production, and the cost effectiveness of selected herbicide treatments.

\section{Materials and methods}

An experiment was established to determine the cost effectiveness of various herbicide treatment programs for leafy spurge control at two locations in North Dakota. The sites included a mixed grass prairie (Altamont vegetation zone) on a federal game management area near Valley City in eastern North Dakota and a mixed grass pasture (Missouri Slope vegetation zone) near New England in western North Dakota $(15,16)$. The areas were fenced to prevent grazing. The estimated annual vegetative production ranges from 2630 to $3530 \mathrm{~kg} / \mathrm{ha}$ in the eastern location (Altamont zone) and from 2020 to 2690 $\mathrm{kg} / \mathrm{ha}$ in the western location (Missouri Slope zone) depending on growing conditions.

The main grasses were several bluegrasses (Poa spp.) with occasional crested wheatgrass (Agropyron desertorum Roemer and Schultes), western wheatgrass (Agropyron smithii Rydb.), and smooth brome (Bromus inermis Leyss. \# BROIN). Both sites had at least an $80 \%$ ground cover of leafy spurge and the eastern location was sparsely infested with western snowberry (Symphoricarpos occidentalis Hook. \# SYPOC) and prairie wild rose (Rosa arkansana Porter \# ROSAK). Soil properties and annual precipitation received during the experiment are listed in Table 1.

The treatments were selected based on cost and efficacy of leafy spurge control as determined from previous research $(4,7)$ and included 2,4-D at $2.2 \mathrm{~kg} / \mathrm{ha}$, picloram plus 2,4-D at 0.28 plus $1.1 \mathrm{~kg} / \mathrm{ha}$, picloram at $2.2 \mathrm{~kg} / \mathrm{ha}$, and dicamba at $9 \mathrm{~kg} / \mathrm{ha}$. Initial treatments were applied in Aug., 1983 or June, 1984 as fall- or spring-applied treatments, respectively. Thereafter, the spring-applied herbicides were applied during the leafy spurge true-flower growth stage and the fall-applied herbicides were applied during fall regrowth in 1984 through 1988.

Page 2 of 10 
Table 1. Physical and chemical characteristics of soils and annual precipitation at the two experimental sites in eastern (Valley City) and western. (New England) North Dakota.

\begin{tabular}{|c|c|c|c|c|c|c|c|c|c|c|c|c|c|c|c|c|}
\hline \multirow[b]{3}{*}{ Location } & \multirow[b]{3}{*}{ Soil type } & \multirow[b]{3}{*}{ Sand } & \multirow[b]{3}{*}{ Silt } & \multirow[b]{3}{*}{ Clay } & \multirow{3}{*}{$\begin{array}{l}\text { Organic } \\
\text { Matter }\end{array}$} & \multirow[b]{3}{*}{$\mathrm{pH}$} & \multicolumn{10}{|c|}{ Precipitation and year } \\
\hline & & & & & & & \multicolumn{2}{|c|}{1984} & \multicolumn{2}{|c|}{1985} & \multicolumn{2}{|c|}{1986} & \multicolumn{2}{|c|}{1987} & \multicolumn{2}{|c|}{1988} \\
\hline & & & & & & & Total & Dev. $^{\mathrm{a}}$ & Total & Dev & Total & Dev & Total & Dev & Total & Dev \\
\hline & & $\longrightarrow$ & 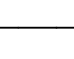 & $\%$ & 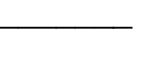 & & & & & & - & $\mathrm{n}$ & 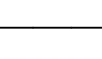 & & & + \\
\hline Eastern & $\begin{array}{c}\text { Barnes } \\
\text { stoney } \\
\text { loam }\end{array}$ & 40 & 40 & 20 & 5.0 & 6.3 & 38.8 & -8 & 42.3 & -4.5 & 67.4 & 20.6 & 44 & -2.8 & 38.2 & -8.6 \\
\hline Western & $\begin{array}{l}\text { Felor } \\
\text { loam }\end{array}$ & 19 & 45 & 36 & 5.8 & 6.7 & 45.2 & 5.2 & 43.1 & 3.1 & 53.8 & 13.7 & 39.2 & -0.8 & 23.3 & -16.7 \\
\hline
\end{tabular}


The 2,4-D at $2.2 \mathrm{~kg} / \mathrm{ha}$ and picloram plus 2,4-D at $0.28 \mathrm{plus} 1.1 \mathrm{~kg} / \mathrm{ha}$ were applied annually, while picloram at $2.2 \mathrm{~kg} / \mathrm{ha}$ and dicamba at $9 \mathrm{~kg} / \mathrm{ha}$ were reapplied when leafy spurge top growth control declined to $70 \%$ or less. Herbicides were applied in water to 5by $15-\mathrm{m}$ plots using a tractor-mounted sprayer delivering $75 \mathrm{~L} / \mathrm{ha}$ at $240 \mathrm{kPa}$. The experiment was a randomized complete block design with four replications at both locations.

Forage yield was determined in July of 1984 through 1988 by harvesting 1.2 by $7.6 \mathrm{~m}$ in each plot with a rotary mower. Mowing alone may affect leafy spurge, and forage production (7), so a different quarter of the plot was harvested each year with only the 1984 and 1988 samples taken from the same plot area. Three $0.25-\mathrm{m}^{2}$ samples were taken by hand along each harvested strip and were separated into forage and leafy spurge components so percent leafy spurge and forage weight in the mowed samples could be calculated. The samples were oven dried at $60 \mathrm{C}$ and are reported with a $12 \%$ moisture content.

Economic data was estimated by converting forage production to hay sold for $\$ 40 / \mathrm{Mg}$, the average 5-year price (12), minus the cost of the herbicide and estimated application cost of $\$ 5 / \mathrm{ha}$. The average herbicide costs during the experiment were 2,4-D at $\$ 4.50 / \mathrm{kg}$, dicamba at $\$ 27.45 / \mathrm{kg}$, and picloram at $\$ 90 / \mathrm{kg}$. Data were analyzed using the general linear models procedure with LSD mean separation (14).

\section{Results and discussion}

The annual forage production in the untreated control averaged 2100 and $920 \mathrm{~kg} / \mathrm{ha}$ at the eastern (Altamont zone) and western (Missouri Slope zone) North Dakota locations, respectively, (10480 and $4610 \mathrm{~kg} /$ ha total for 5 years) (Table 2). Concurrently, leafy spurge top growth averaged 1730 and $650 \mathrm{~kg} / \mathrm{ha}(8630$ and $3230 \mathrm{~kg} / \mathrm{ha}$ total) in eastern and western North Dakota, respectively, or an average of $43 \%$ of the total production. The approximate annual forage production (excluding forbs and shrubs) in these vegetation zones is 2460 and $1880 \mathrm{~kg} / \mathrm{ha}$ in eastern and western North Dakota, respectively (15, 16). Thus, leafy spurge caused at least a $50 \%$ loss in forage production at the more arid, less productive site in western North Dakota compared to only a $15 \%$ decrease in production in eastern North Dakota even though the percent leafy spurge infestation was similar.

All treatments provided at least short-term top growth control (data not shown) and reduced leafy spurge production (Table 2). The best treatments for leafy spurge control in eastern North Dakota were picloram at $2.2 \mathrm{~kg} / \mathrm{ha}$ and dicamba at $9 \mathrm{~kg} / \mathrm{ha}$ fall-applied twice with 90 and 70\% leafy spurge control, respectively. These treatments reduced leafy spurge production to a total of 330 and $860 \mathrm{~kg} / \mathrm{ha}$, respectively, compared to $8630 \mathrm{~kg} / \mathrm{ha}$ in the control.

The best treatments in western North Dakota which controlled 90 to $100 \%$ of the leafy spurge were picloram plus 2,4-D at 0.28 plus $1.1 \mathrm{~kg} / \mathrm{ha}$, picloram at $2.2 \mathrm{~kg} / \mathrm{ha}$, and dicamba at $9 \mathrm{~kg} / \mathrm{ha}$, all spring applied (Table 2). However, leafy spurge growth was reduced similarly by most treatments with an average total leafy spurge production of 245 $\mathrm{kg} / \mathrm{ha}$, excluding fall-applied 2,4-D and picloram plus 2,4-D which reduced leafy spurge growth to an average 5 -year total of $1485 \mathrm{~kg} / \mathrm{ha}$.

Page 4 of 10 
Table 2. Leafy spurge control, forage production, and estimated net return from several herbicide treatments in eastern and western North Dakota during a 5-year management program.

\begin{tabular}{|c|c|c|c|c|c|c|c|}
\hline \multirow{2}{*}{$\begin{array}{l}\text { Original } \\
\text { treatment date and } \\
\text { herbicide }\end{array}$} & \multirow[b]{2}{*}{ Rate } & \multirow{2}{*}{$\begin{array}{l}\text { Retreat- } \\
\text { ment ap- } \\
\text { plied }\end{array}$} & \multirow[b]{2}{*}{ Cost } & \multirow{2}{*}{$\begin{array}{l}\text { Control } \\
\text { Aug. } \\
1988^{\mathrm{a}}\end{array}$} & \multicolumn{2}{|c|}{ Total yield } & \multirow{2}{*}{$\begin{array}{l}\text { Total ne } \\
\text { return }\end{array}$} \\
\hline & & & & & Forage & Leafy Spurge & \\
\hline & $\mathrm{kg} / \mathrm{ha}^{-1}$ & Year & $\$ /$ ha & $\%$ & $\longrightarrow$ & $\mathrm{g} / \mathrm{ha}^{-1}$ & $\$ \mathrm{ha}^{-1}$ \\
\hline \multicolumn{5}{|l|}{ Spring 1994} & \multicolumn{3}{|c|}{ Eastern North Dakota } \\
\hline $2.4-\mathrm{D}$ & 2.2 & $85-88$ & 75 & 30 & 10870 & 4170 & 356 \\
\hline Picloram + 2,4- $\mathrm{D}^{\mathrm{b}}$ & $0.28+1.1$ & $85-88$ & 175 & 70 & 11480 & 2210 & 284 \\
\hline Picloram $^{\mathrm{c}}$ & 2.2 & 1988 & 405 & 100 & 12770 & 1760 & 105 \\
\hline Dicamba $^{\mathrm{c}}$ & 9 & $85,86,87$ & 1010 & 90 & 12180 & 2230 & -523 \\
\hline \multicolumn{8}{|l|}{ Fall 1983} \\
\hline $2,4-\mathrm{D}^{\mathrm{b}}$ & 2.2 & $84-87$ & 75 & 0 & 8320 & 7390 & 258 \\
\hline Picloram + 2,4- $\mathrm{D}^{\mathrm{b}}$ & $0.28+1.1$ & $84-87$ & 175 & 20 & 10890 & 3830 & 261 \\
\hline Picloram $^{\mathrm{c}}$ & 2.2 & 1985 & 405 & 90 & 12310 & 330 & 87 \\
\hline Dicamba $^{c}$ & 9 & 1986 & 505 & 70 & 12080 & 860 & -20 \\
\hline Control & $\ldots$ & $\ldots$ & 0 & 0 & 10480 & 8630 & \\
\hline $\operatorname{LSD}(0.05)$ & & & & 15 & 1600 & 850 & 60 \\
\hline \multicolumn{5}{|l|}{ Spring 1984} & \multicolumn{3}{|c|}{ Western North Dakota } \\
\hline $2,4-D^{b}$ & 2.2 & $85-88$ & 75 & 40 & 4780 & 590 & 116 \\
\hline Picloram $+2,4-\mathrm{D}^{\mathrm{b}}$ & $0.28+1.1$ & $85-88$ & 175 & 90 & 7070 & 180 & 108 \\
\hline Picloram $^{c}$ & 2.2 & 86,87 & 610 & 100 & 6920 & 140 & -333 \\
\hline Dicamba $^{c}$ & 9 & $85,86, .87$ & 1010 & 100 & 5670 & 390 & -783 \\
\hline \multicolumn{8}{|l|}{ Fall 1983} \\
\hline $2,4-\mathrm{D}^{\mathrm{b}}$ & 2.2 & $84-87$ & 75 & 10 & 5520 & 1550 & 146 \\
\hline Picloram + 2.4- $\mathrm{D}^{\mathrm{b}}$ & $0.28+1.1$ & $84-87$ & 175 & 20 & 5110 & 1420 & 29 \\
\hline Picloram $^{\mathrm{c}}$ & 2.2 & 1986 & 405 & 70 & 6690 & 50 & -137 \\
\hline Dicamba $^{c}$ & 9 & 85,86 & 755 & 60 & 6280 & 120 & -504 \\
\hline Control & & & 0 & 0 & 4610 & 3230 & \\
\hline $\operatorname{LSD}(0.05)$ & & & & 20 & 850 & 450 & 35 \\
\hline
\end{tabular}

${ }^{\mathrm{a} C}$ Control 12 mo after last treatment.

${ }^{\mathrm{b}}$ Annual retreatment.

${ }^{\mathrm{c}}$ Retreated when control declined to less than $70 \%$.

All treatments reduced the leafy spurge infestation at both locations except 2,4-D at $2.2 \mathrm{~kg} / \mathrm{ha}$ applied in the spring or fall and picloram plus 2,4-D at $0.28 \mathrm{plus} 1.1 \mathrm{~kg} / \mathrm{ha}$ fall applied, which only averaged $20 \%$ control (Table 2). Dicamba at $9 \mathrm{~kg} / \mathrm{ha}$ had to be spring applied four times in 5 years at both locations to maintain at least $70 \%$ leafy spurge control with a total cost of $\$ 1010 / \mathrm{ha}$. Dicamba at $9 \mathrm{~kg} / \mathrm{ha}$ generally controls about $70 \%$ of the leafy spurge top growth 12 mo after treatment in North Dakota (5) but apparently did not reduce the leafy spurge root system appreciably after several annual applications despite the decrease in top growth since regrowth occurred rapidly. 
To maintain at least $70 \%$ leafy spurge control, picloram at $2.2 \mathrm{~kg} / \mathrm{ha}$ was reapplied once as a spring- or fall-applied treatment in eastern North Dakota and as a fall-applied treatment in western North Dakota (Table 2). However, picloram was reapplied twice in the spring at the western location in 1986 and 1987 because control was only 50\% 12 mo after the 1986 treatment (data not shown). Although the maximum control after 1 year was usually 94 to $100 \%$, picloram at $2.2 \mathrm{~kg}$ /ha occasionally failed to control leafy spurge $(5,6)$. The reasons for the occasional failure are not known. Picloram absorption is decreased by cool temperature and low humidity (11), but air temperature was $22 \mathrm{C}$ with $42 \%$ relative humidity when the treatment was applied in 1986. Also, the plants were in the true-flower growth stage so treatment conditions should have been favorable.

Despite the large decrease in leafy spurge growth, forage production in eastern North Dakota was increased only slightly by four treatments (Table 2). Picloram at $2.2 \mathrm{~kg} / \mathrm{ha}$ and dicamba at $9 \mathrm{~kg} / \mathrm{ha}$ applied in the spring or fall provided similar total forage production and averaged $12340 \mathrm{~kg} / \mathrm{ha}$ which is similar to the expected 5-year regional average (15). All but two treatments at the western location increased total forage production compared to the control (Table 2), but all were below the regional average of $1800 \mathrm{~kg} / \mathrm{ha}$ annually (9000 kg/ha for 5 years) (16). Picloram plus 2,4-D at 0.28 plus $1.1 \mathrm{~kg} / \mathrm{ha}$ spring applied, dicamba at $9 \mathrm{~kg} / \mathrm{ha}$ fall applied, and picloram at $2.2 \mathrm{~kg} / \mathrm{ha}$ spring or fall applied provided the most total forage production, in western North Dakota with a 5-year average of $6740 \mathrm{~kg} / \mathrm{ha}$.

All treatments provided a positive economic return in eastern North Dakota except dicamba (Table 2). The greatest net return of $\$ 356 /$ ha was achieved with 2,4-D at 2.2 $\mathrm{kg} / \mathrm{ha}$ spring applied. However, 2,4-D only controlled the top growth and a retreatment would be required indefinitely (6). The most cost-effective treatment, considering both leafy spurge control and forage production, was picloram plus 2,4-D at 0.28 plus 1.1 $\mathrm{kg} / \mathrm{ha}$ spring applied. This treatment resulted in a net return of $\$ 284 / \mathrm{ha}$ and had gradually reduced the leafy spurge infestation by 70\%. 2,4-D or picloram plus 2,4-D fall applied did provide a positive economic return but did not control leafy spurge satisfactorily.

Several treatments provided a positive economic return in western North Dakota, but the total return was much smaller compared to eastern North Dakota because of lower forage production (Table 2). Again picloram plus 2,4-D spring applied was the most costeffective treatment which resulted in $90 \%$ leafy spurge control, $7070 \mathrm{~kg} / \mathrm{ha}$ forage production, and a net return of $\$ 108 / \mathrm{ha}$. 2,4-D at $2.2 \mathrm{~kg} / \mathrm{ha}$ applied in the spring or fall resulted in a net return of $\$ 116$ and $\$ 146 /$ ha, respectively, but did not reduce the leafy spurge infestation appreciably.

Picloram at $2.2 \mathrm{~kg} / \mathrm{ha}$ spring or fall applied in eastern North Dakota provided 90 to $100 \%$ leafy spurge control and a positive net return of $\$ 105$ or $\$ 87 /$ ha, respectively (Table 2). However, despite good leafy spurge control at the western location, picloram at $2.2 \mathrm{~kg} / \mathrm{ha}$ spring or fall applied resulted in a net loss of $\$ 333$ and $\$ 137 / \mathrm{ha}$, respectively, because of the lower forage production and treatment failure in 1986. Dicamba at $9 \mathrm{~kg} / \mathrm{ha}$ resulted in an average net loss of $\$ 458 / \mathrm{ha}$.

Evaluation of the 5-year total leafy spurge control and forage production does not reveal the year-to-year variability (Table 2 ). The variability was similar for all treatments so the picloram plus 2,4-D treatment was chosen to illustrate this point (Figures 1 and 2). 


\section{A. SPRING}

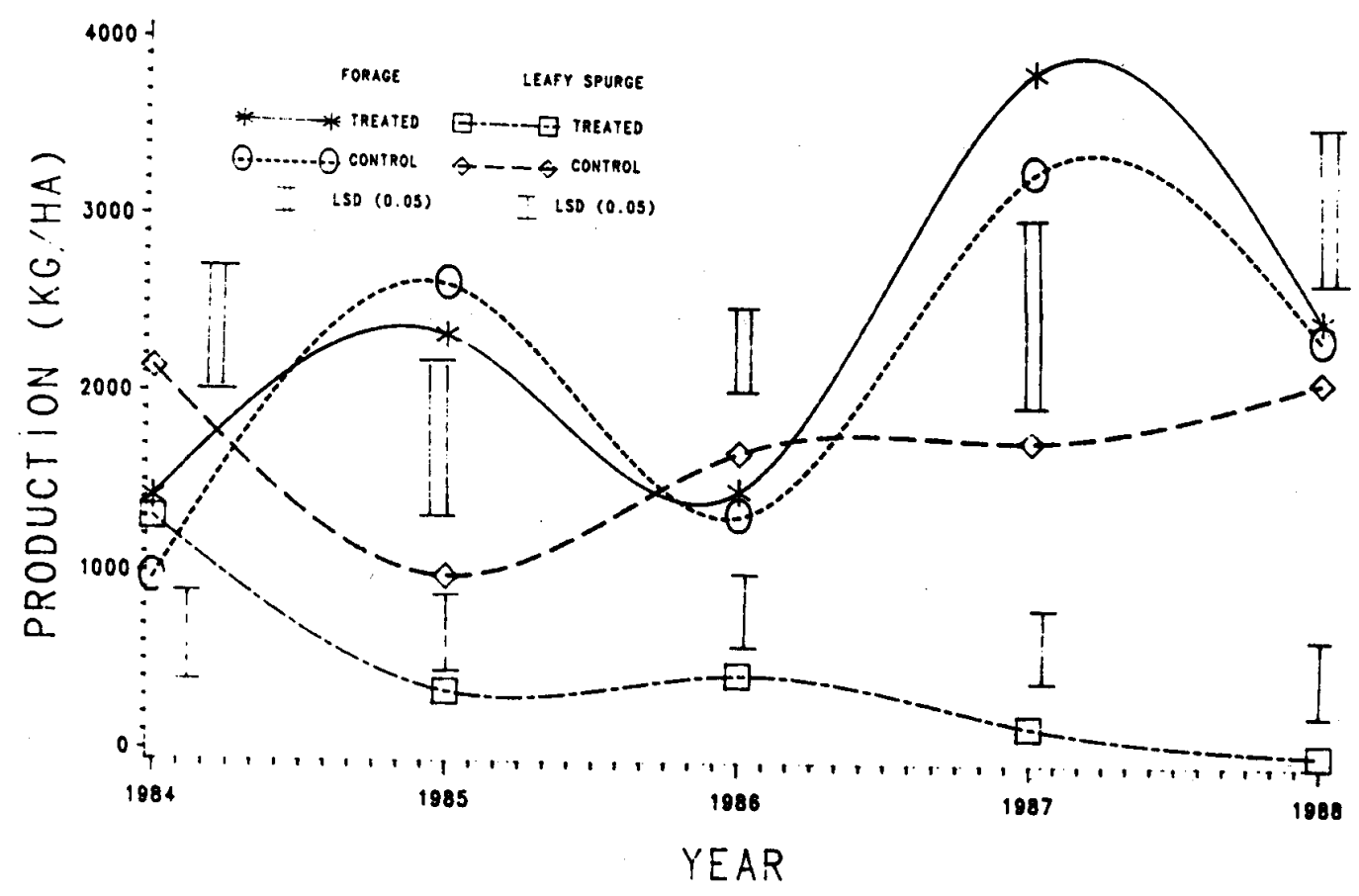

B. FALI,

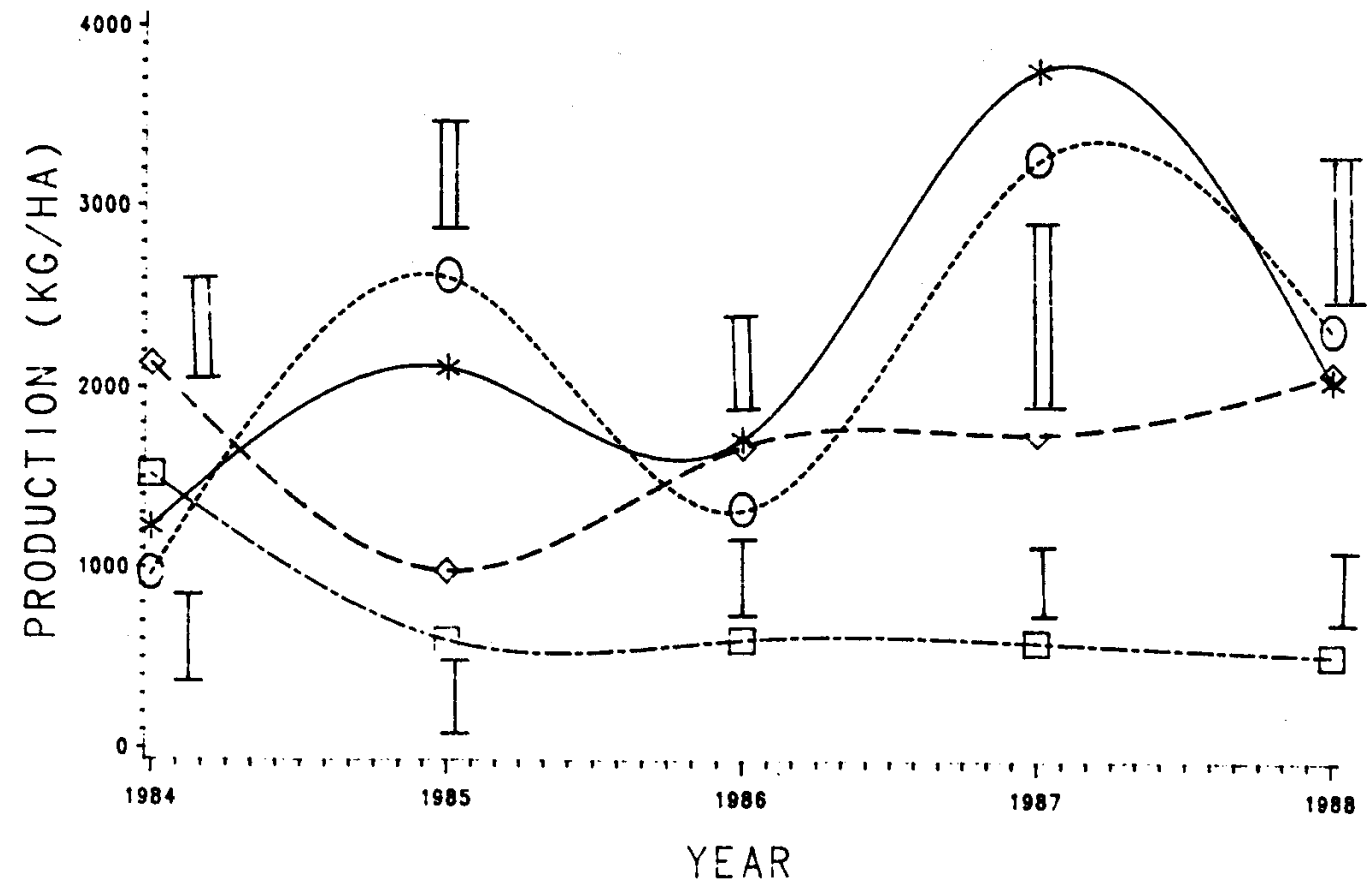

Figure 1. Leafy spurge and forage production following picloram plus 2,4-D at 0.28 plus 1.1 $\mathrm{kg} / \mathrm{ha}^{-1}$ applied annually in the spring (A) or fall (B) in eastern (Valley City) North Dakota. 


\section{A. SPRING}

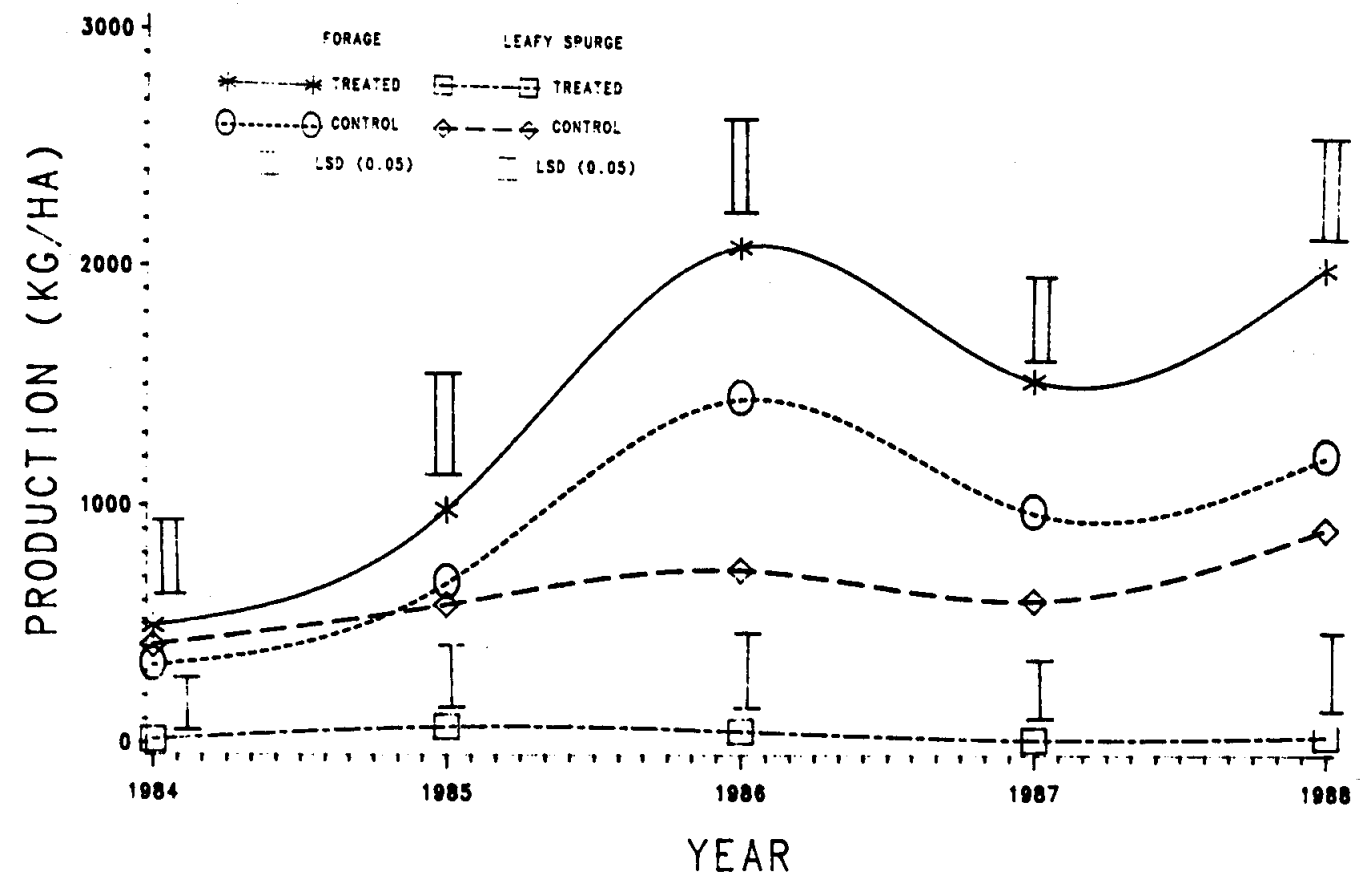

B. FALL

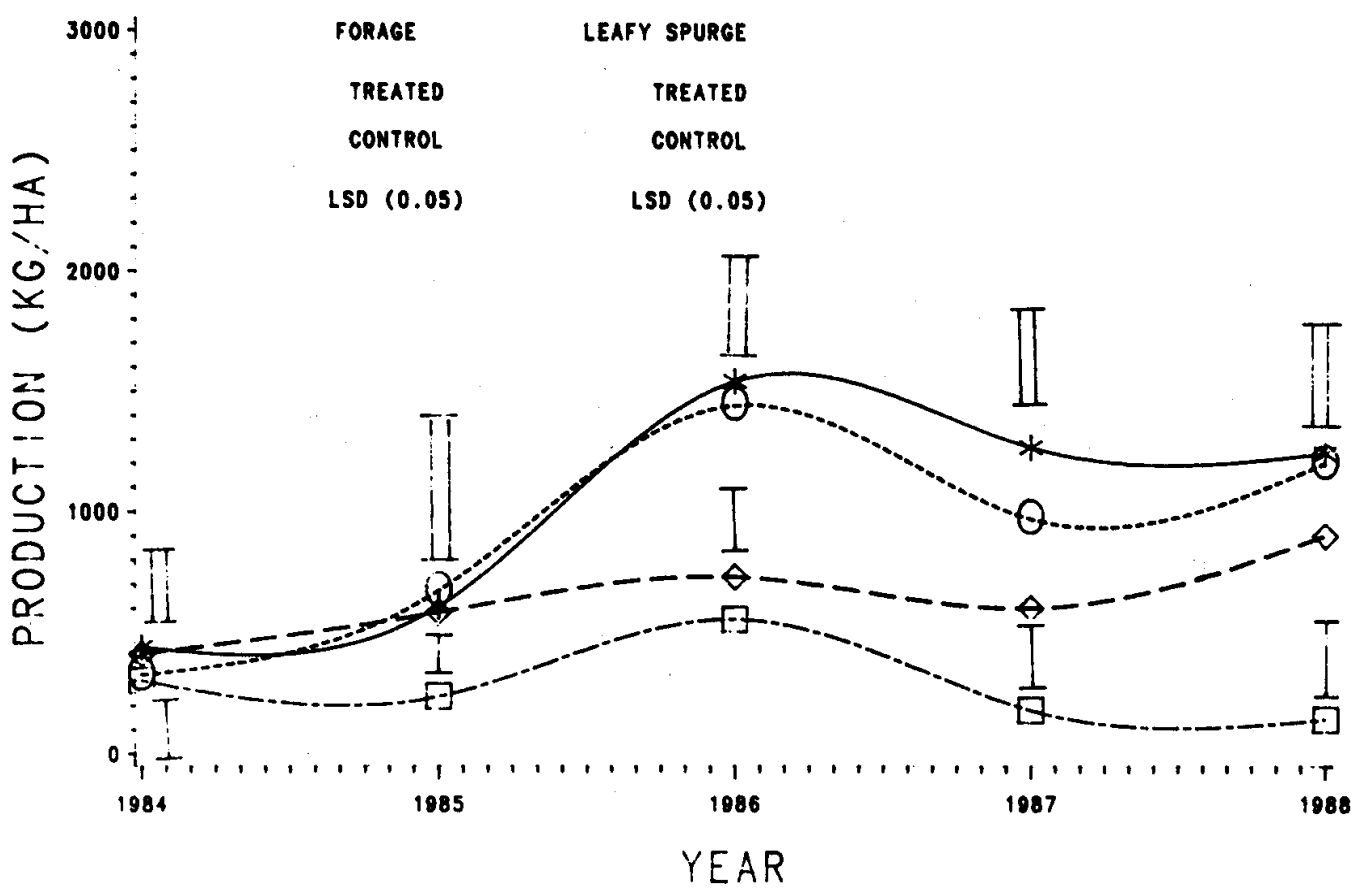

Figure 2. Leafy spurge and forage production following picloram plus 2,4-D at 0.28 plus 1.1 $\mathrm{kg} \mathrm{ha}^{-1}$ applied annually in the spring (A) or fall (B) in western (New England) North Dakota. 
Forage production in the untreated control in eastern North Dakota varied widely from year to year, ranging from $950 \mathrm{~kg} / \mathrm{ha}$ in 1984 to $3270 \mathrm{~kg} / \mathrm{ha}$ in 1987 (Figure 1A). Precipitation was $20.6 \mathrm{~cm}$ above the long-term average in 1986 (Table 1), which probably accounts for the increased production in 1987. Leafy spurge production was slightly less variable from year to year and ranged from $2130 \mathrm{~kg} / \mathrm{ha}$ in 1984 to $980 \mathrm{~kg} / \mathrm{ha}$ in 1985 . Picloram plus 2,4-D at 0.28 plus $1.1 \mathrm{~kg} / \mathrm{ha}$ spring applied annually gradually reduced leafy spurge production to $0 \mathrm{~kg} / \mathrm{ha}$ in 1988 , but annual forage production only tended to be greater than the control.

Picloram plus 2,4-D at 0.28 plus $1.1 \mathrm{~kg} / \mathrm{ha}$ reduced leafy spurge production after the first fall treatment, but subsequent treatments did not reduce growth further. Forage production was similar to the control throughout the experiment.

Unlike in the east, picloram plus 2,4-D spring applied annually in western North Dakota increased forage production every year after the first two treatments compared to the control . Leafy spurge production was reduced to an average of $10 \mathrm{~kg} / \mathrm{ha}$ in $198412 \mathrm{mo}$ after the first treatment and remained near that amount thereafter. Picloram plus 2,4-D at 0.28 plus $1.1 \mathrm{~kg} / \mathrm{ha}$ fall applied in western North Dakota resulted in forage production similar to the control and generally reduced leafy spurge production.

A specific treatment may not provide a positive net return each year, but several treatments were cost effective over the 5 -year study period. Total potential production and value of the forage will determine if a specific treatment is cost effective in any one location. Since all treatments provided at least short-term top growth control they all would allow increased forage utilization by cattle. However, since cattle avoid grazing in areas with even a $10 \%$ infestation $(2,3)$, treatments that only provide short-term top growth control are of minimal value.

Treatment with 2,4-D at $2.2 \mathrm{~kg} / \mathrm{ha}$ always provided a positive net return but caused only a small reduction in leafy spurge density. This short-term reduction may allow the pasture to be hayed and the forage utilized. However, annual 2,4-D treatments did not increase forage production compared to the control (Table 2) and mowing may even cause increased leafy spurge top growth (7). When reduced leafy spurge density is an objective, not just short-term top growth control, picloram plus 2,4-D at 0.28 plus $1.1 \mathrm{~kg} / \mathrm{ha}$ was cost effective in both high- and low-production areas and would be the treatment of choice in most instances. However, picloram at $2.2 \mathrm{~kg} / \mathrm{ha}$ may be cost effective in areas of high production or where satisfactory leafy spurge control is required for several years without a retreatment.

\section{Literature cited}

1. Alley, H. P., N. E. Humburg, J. K. Fornstrom, and M. Ferrell. 1984. Leafy spurge control with repetitive herbicide treatments. Res. Weed Sci., Wyo. Agric. Exp. Stn. Res. J. 192:90-93.

2. Hein, D. G. 1988. Single and repetitive picloram treatments on leafy spurge (Euphorbia esula L.) and resulting changes in shoot density, canopy cover, forage production, and utilization by cattle. Ph.D. thesis. Univ. of Wyo. Univ. Microfilms. Ann Arbor, MI (Diss. Abstr. AAD8827917).

3. Lym, R. G., and D. R. Kirby. 1987. Cattle foraging behavior in leafy spurge (Euphorbia esula)-infested rangeland. Weed Technol. 1:314-318.

Page 9 of 10 
4. Lym, R. G., and C. G. Messersmith. 1985. Cost effectiveness of leafy spurge control during a five-year management program. N.D. Farm Res. 43(1):7-9, 14.

5. Lym, R. G., and C. G. Messersmith. 1985. A summary of leafy spurge control with herbicides in North Dakota since 1963. N. D. Farm Res. 43(1):3-6.

6. Lym R. G., and C. G. Messersmith. 1985. Leafy spurge control with herbicides in North Dakota: 20-year summary. J. Range Manage. 38: 149-154.

7. Lym, R. G., and C. G. Messersmith. 1985. Leafy spurge control and improved forage production with herbicides. J. Range Manage. 38:386-391.

8. Lym, R. G., and C. G. Messersmith. 1987. Leafy spurge control and herbicide residue from annual picloram and 2,4-D application. J. Range Manage. 40:194-198.

9. Messersmith, C. G., and R. G. Lym. 1983. Distribution and economic impacts of leafy spurge in North Dakota. N. D. Farm Res. 40(5):8-13.

10. Messersmith, C. G., and R. G. Lym. 1985. Roller application of picloram for leafy spurge control in pasture. Weed Sci. 33:258-262.

11. Moxness, K. D., and R. G. Lym 1989. Environment and spray additive effects on picloram absorption and translocation in leafy spurge (Euphorbia esula). Weed Sci. 37:181-186.

12. North Dakota Agricultural Statistics. 1989. N.D. Agric. Statistics Serv., No. 58. Bismarck, ND.

13. Reilly, W., and K. R. Kaufman. 1979. The social and economic impact of leafy spurge in Montana. p. 21-24 in Proceedings: Leafy spurge symposium. N. D. State Univ. Coop. Ext. Serv., Unnumbered publication.

14. Statistical Analysis System Institute. 1985. SAS User's Guide: Statistics. Cary, NC.

15. U.S. Soil Conservation Service. 1984. Technical guide. Notice ND-35. Bismarck, ND.

16. Wright M R., J. R. Schaar, and S. J. Tillotson. 1982. Soil survey of Dunn County, North Dakota. USDA Soil Conserv. Serv., Bismarck, ND. 